Pediat. Res. 13: 868 (1979)

\title{
Letter to the Editor: Preservation of Mitochondrial Enzymes in Brain and Muscle in Reye's Syndrome
}

\author{
JACQUELINE S. PARTIN \\ Electron Microscope Laboratory, Children's Hospital Research Foundation, Cincinnati, Ohio, USA
}

Robinson et al. (4) reported normal activities of the mitochondrial enzymes citrate synthase, succinic dehydrogenase, and glutamate dehydrogenase from brains of children who had died with Reye's syndrome, and normal activities of citrate synthase, succinic dehydrogenase, and pyruvate dehydrogenase from muscle of children who had died with Reye's syndrome. The authors use these assays of autopsy tissue as a basis to propose that the ultrastructural mitochondrial alterations which we have described in brain $(1,3)$ and muscle $(2)$ biopsies are either a secondary phenomenon or are "representative of the same primary process that occurs in liver mitochondria but without the same biochemical sequelae."

In our studies of brain biopsies from three children with Reye's syndrome $(1,3)$, we found that only the mitochondria in the neurons were altered. Because neurons compose only a small fraction of the cerebral cortical mass, it appears to us that $\mathrm{Dr}$. Robinson's autopsy tissue measurements would not be expected to reflect mitochondrial alterations which are limited to this small class of cells.

The same argument holds for measurement of muscle mitochondrial enzyme activity. We reported severe alterations in only about 1 in 40 muscle cells. Further, we described two populations of mitochondria, the majority showing only slight matrix expansion. It would seem highly unlikely that measurement of whole muscle mitochondrial enzyme activity would reflect such selective mitochondrial injury. The uniform mitochondrial injury in a homogeneous organ like the liver would not surprisingly yield the result of enzymatic analysis found by Robinson et al. (4).

Failure to find biochemical evidence of mitochondrial injury in whole tissue homogenates of autopsy tissue is insufficient evidence that neuronal mitochondria and skeletal muscle mitochondria are uninjured in Reye's syndrome. Electron microscopy of instantaneously fixed biopsy tissue may be a more sensitive indicator of injury to mitochondrial populations which are beyond the resolution of the whole tissue homogenate method.

\section{REFERENCES AND NOTES}

1. Partin, J. S., McAdams, A. J., Partin, J. C., Schubert, W. K., and McLaurin, R. L.: Brain ultrastructure in Reye's syndrome II: Acute injury and recovery processes in three children. J. Neuropath. Exp. Neurol. 37: 796 (1978).

2. Partin, J. C., Partin, J. S., and Schubert, W. K.: Muscle ultrastructure in Reye's syndrome (RS): Evidence for a myopathy. Pediatr. Res. 11: 1156 (1977).

3. Partin, J. C., Partin, J. S., Schubert, W. K., and McLaurin, R. L.: Brain ultrastructure in Reye's syndrome (encephalopathy and fatty alteration of the viscera). J. Neuropath. Exp. Neurol. 34: 425 (1975).

4. Robinson, B. H., Taylor, J., Cutz, E., and Gall, D. G.: Reye's syndrome: Preservation of mitochondrial enzymes in brain and muscle compared with liver. Pediatr. Res. 12: 1045 (1978).

5. Received for publication December 8, 1978.

6. Accepted for publication January 11, 1979. 